\title{
Ellipsis
}

2014

\section{This is Halloween}

Lauren Underwood

University of New Orleans

Follow this and additional works at: https://scholarworks.uno.edu/ellipsis

Part of the Nonfiction Commons

\section{Recommended Citation}

Underwood, Lauren (2014) "This is Halloween," Ellipsis: Vol. 41 , Article 28.

DOI: https://doi.org/10.46428/ejail.41.28

Available at: https://scholarworks.uno.edu/ellipsis/vol41/iss1/28

This Creative Nonfiction is brought to you for free and open access by the Department of English and Foreign Languages at ScholarWorks@UNO. It has been accepted for inclusion in Ellipsis by an authorized editor of ScholarWorks@UNO. For more information, please contact scholarworks@uno.edu. 


\section{This is Halloween \\ Lauren Underwood}

I was three, and it was Halloween night. My dad was working, so Mom and I were on our own, not to discount my little brother, Alex, still in utero. She took me around to a couple of houses on our block, but what I remember best was trick-or-treating in my grandparents' neighborhood. Mom always dolled me up in seasonal dresses with coordinating headbands, but I never really had a costume. This year she outfitted me in a sweater with pumpkins of varying sizes along the hem. When we got to my grandparents' house, my aunts and uncles had already huddled up with their kids and made a game plan of which streets they would hit up.

I surveyed my cousins - a ninja, a witch, a ballerina, and a brother and sister dressed as Dalmatians. I felt like the odd girl out. I may have asked, or even demanded, to dress up like the other kids. My mother obliged. I delighted in my first Halloween costume - a piteous shamble of a ghost, fashioned from an old pillowcase with a pair of scissors and a red magic marker only minutes before we walked out the door though there was ample time to photograph the magic moment.

Underneath that pillowcase, I became invisible. I peered through two gaping eyeholes at the grown-ups looming over me, astounded that I could watch people who weren't able to see all of me. Empowered by my newfound anonymity, I shuffled from door to door in my pink Keds with a gaggle of costumed toddlers, responding to the appropriate cues.

"You say 'Trick or treat!' when someone answers the door," my mother instructed. "You say 'Thank you' once they put the candy in your bag."

I was confused whenever we had to stray from the script. A porch light turned off signaled the occupant wasn't home - or as I know now, possibly just not entertaining trick-or-treaters. There would be the house with a huge bowl of candy outside the door and a note directing to "Take one only, please." There were houses where we bobbed for apples on the front lawn or timidly tiptoed through homemade haunted fabrications in driveways and garages.

Skeletons sprang upright in Styrofoam coffins; monsters and horror movie villains pervaded the suburb streets. I might have been startled by some of the things that I saw, but very little phased me because in my imagination, I was a ghost. I was impervious to fear. If anything, people needed to fear me. And I crept 
up behind several people who may have been genuinely frightened or who may have simply been playing along when I shouted "Boo!"

Fast-forward sixteen years to my life as a college freshman "displaced" by Hurricane Katrina. Living temporarily in St. Amant, Louisiana. Spending a Halloween Monday curled in a ball on an itchy sofa that wasn't mine, shrouded in hand-made quilts, watching My So-Called Life marathons until the early-morning hours. My So-Called Life, a one-season wonder in which Claire Danes plays Angela Chase, delivering one of the most realistic depictions of what it's like to be a teenage girl. I remembered the series from childhood. I would sneak-watch it when I was eight or nine.

My mother walked in once when Rayanne Graff, Angela's new best friend, was sprawled out drunk on the bathroom floor.

"What is this?" My mother glowered and slammed her palm down on the power button before sending me to bed.

When I saw Angela Chase's fire-engine-red bob on the screen years later, I was drawn in. I felt mischievous, looking over my shoulder, half-expecting to see my mother there, hand on hip, shaking her head in disappointment at the poor choice I'd made to watch this program and at all the subsequent poor choices I'd undoubtedly make.

There I was, in a valium-induced lull, engorged on chocolate from the Piggly Wiggly down the road, sad to be on my own, completely entranced by this program. I began pondering who I was, where I would end up. Through the quietly beautiful Angela Chase, I had a mini-epiphany. I have the ability to shape my own identity. Changing who you are friends with, changing the music you listen to, the way you see your parents, even changing your hair-could change your life.

As I get older, I've felt a significant disconnect between how old I am and how old I feel. But Halloween blurs the lines between nostalgic appreciation and reversion back to my childhood ways. Even as an adult, it's acceptable to feel giddy about being able to play dress-up. We all ask each other, "Who (or what) are you going to be?"

Some otherworldly force takes effect whenever Halloween draws near, and I find true pleasure in submitting to it.

There are endless possibilities for transformation. 